\title{
Cytokine Production Inhibitors Produced by a Fungus, Oidiodendron griseum
}

\author{
Katsuomi Ichikawa*, Hideo Hirai, Masaru Ishiguro, Takahito Kambara ${ }^{\dagger}$, Yoshinao Kato, \\ Yoon Jeong Kim, Yasuhiro Kojima, Yasue Matsunaga, Hiroyuki Nishida,

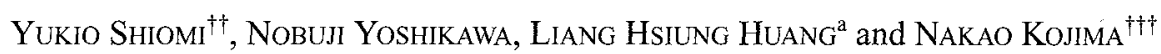 \\ Exploratory Medicinal Sciences, PGRD, Nagoya Laboratories, Pfizer Pharmaceuticals Inc., \\ 5-Gochi, Taketoyo-cho, Chita-gun, Aichi 470-2393, Japan \\ ${ }^{\text {a }}$ PGRD, Groton Laboratories, Pfizer Inc., \\ Eastern Point Road, Groton, CT 06340, USA
}

(Received for publication May 9, 2001)

\begin{abstract}
A series of diterpenes were isolated from the fermentation broth of a fungus, Oidiodendron griseum CL37215. The diterpenes were identified as LL-Z1271 $\alpha$, LL-Z1271 $\gamma$, CJ-14,445, PR 1388, CJ-14,604 and a new diterpene, CJ-14,515. They inhibited both lipopolysaccharide-induced interleukin- $1 \beta$ and tumor necrosis factor- $\alpha$ production in human whole blood with $\mathrm{IC}_{50} \mathrm{~s}$ of the range from 0.049 to $100 \mu \mathrm{M}$.
\end{abstract}

Cytokines are produced by a variety of different cell types and act on nearly every tissue and organ ${ }^{1)}$. Among identified cytokines, interleukin- $1 \beta$ (IL-1 $\beta$ ) and tumor necrosis factor- $\alpha$ (TNF- $\alpha$ ) share many properties of immunoregulation and other physiological conditions such as inflammation. Antagonism of IL- $1 \beta$ and TNF- $\alpha$ with the use of natural IL-1 antagonists, soluble receptors, neutralizing antibodies and cytokine production inhibitors has been proven to be beneficial to treatment of inflammatory diseases in animal models and human ${ }^{1 \sim 9)}$. However, their protein-based modulators are unlikely to feasible because of development of immunogenicity and lack of oral availability. Currently available low molecular inhibitors have adverse side effects and poor bioavailability. Consequently, there is still a need for safe and oral active compounds having excellent antagonism of IL- $1 \beta$ and TNF- $\alpha$ such as their receptor antagonists, production inhibitors and signal transduction inhibitors.

In a screening program designed to discover new inhibitors of cytokine production, a fungus Oidiodendron griseum CL37215 was found to produce a series of diterpenes showing inhibitory activities for IL- $1 \beta$ and TNF$\alpha$ production. In this paper, we describe the taxonomy of the producing microorganism, and the fermentation, isolation, structure elucidation and biological activities of the diterpenes.

\section{Results}

Taxonomy of the Producing Microorganism

The cultural characteristics of the strain CL37215 are shown in Table 1. Sporulation was good on all of the media used. The morphological properties were observed on malt extract and potato dextrose agar plates 14 days after inoculation. On malt extract agar, the vegetative mycelium was olive-gray to olive-brown, septate, branched, and measured 1.5 to $4.0 \mu \mathrm{m}$ in diameter. The conidiophores were macronematous, semi-macronematous, micronematous or mononematous, septate, brown to olivaceous brown, smooth, monopodially or verticillately branched, measuring $40 \sim 230 \times 2.0 \sim 3.5 \mu \mathrm{m}$. They may branch up to four levels, with each level two to three subbranches, primary branches being $20 \sim 40 \times 2.0 \sim 3.0 \mu \mathrm{m}$, secondary branches being $15 \sim$ $30 \times 2.0 \sim 2.5 \mu \mathrm{m}$, and tertiary branches being $10 \sim 12 \times 2.0$ $\mu \mathrm{m}$. Conidia were olivaceous to olivaceous green, smooth

Present address: ${ }^{\dagger}$ The Queen’s Veterinary School Hospital, University of Cambridge, Madingley Road, Cambridge CB3 0ES, UK.

${ }^{\dagger \dagger}$ Business Intelligence Department, Pfizer Pharmaceuticals Inc., 2-1-1 Nishi-Shinjuku, Shinjuku-ku, Tokyo 163-0461, Japan.

${ }^{\ddagger \dagger}$ Faculty of Pharmacy, Meijo University, 150 Yagotoyama, Tempaku-ku, Nagoya 468-8503, Japan.

* Corresponding author: katsuomi.ichikawa@japan.pfizer.com 
or slightly roughened, one-celled, oval, elliptical, barrelshaped to elongated, measuring $3.0 \sim 7.0 \times 2.0 \sim 4.0 \mu \mathrm{m}$. They were produced basipetally, maturing from top to bottom, arthrosporic in conidiogenesis. Chlamydospores were not produced. On potato dextrose agar, the morphological properties were similar to those on malt extract agar except that the conidiophores were generally shorter, and the conidia were shorter and narrower, measuring $3.0 \sim 6.0 \times 1.6 \sim 3.0 \mu \mathrm{m}$. The strain could grow well at 20 and $28^{\circ} \mathrm{C}$ but not at 37,45 and $50^{\circ} \mathrm{C}$.

The strain CL37215 was characterized by the slow growth; the olive-gray to dark olive-gray colonies; the olivaceous black to black colony reverse; and the smooth to finely roughened, one-celled, olivaceous conidia which were arthrosporic in nature. It grew well at 20 and $28^{\circ} \mathrm{C}$ but not between 37 and $50^{\circ} \mathrm{C}$. These features fitted into the description of Oidiodendron griseum Robak in the general characteristics of morphologies and the cultural properties ${ }^{10)}$. Minor differences were noted. Some conidiophores were taller and wider, and some conidia were barrel-shaped in addition to being oval to elliptical and were slightly larger than those of the strains of $O$. griseum. As most species of Oidiodendron exhibited a wide range in conidiophore dimensions and conidial shapes, these differences were considered as minor variations. Thus, the strain CL37215 was considered as a new strain of $O$. griseum Robak. It was deposited as FERM BP-5778 at the National Institute of Bioscience and Human-Technology, Agency of Industrial Science and Technology (Tsukuba, Japan).

\section{Isolation}

The fermentation broth (12 liters) treated with the same volume of EtOH was filtered with the aid of celite. The filtrate was concentrated to an aqueous solution (1 liter), and extracted 3 times with the equal volume of EtOAc. The combined organic layers ( 3 liters) were evaporated under reduced pressure to yield an oily residue $(2.8 \mathrm{~g})$. The residue was dissolved in small volume of $\mathrm{MeCN}$ and centrifuged at $2,000 \mathrm{rpm}$. The precipitate and supernatant portions were individually applied to preparative HPLC on an ODS column (YMC-pack ODS AM-343, 20×250 mm,

Table 1. Cultural characteristics of Oidiodendron griseum CL37215.

\begin{tabular}{|c|c|c|c|c|c|}
\hline Medium & Growth & Texture & Colony Surface & Colony Reverse & Soluble Pigment \\
\hline Malt extract & Moderate & $\begin{array}{l}\text { Velvety, thin, } \\
\text { smooth }\end{array}$ & $\begin{array}{l}\text { Olive-gray to deep } \\
\text { olive-gray (LI) }\end{array}$ & $\begin{array}{l}\text { Blackish mouse } \\
\text { gray, olivaceous } \\
\text { black (3) (LI) to } \\
\text { black }\end{array}$ & None \\
\hline Cornmeal & $\begin{array}{l}\text { Poor to } \\
\text { moderate }\end{array}$ & $\begin{array}{l}\text { Velvety, thin, } \\
\text { smooth }\end{array}$ & $\begin{array}{l}\text { Olive-gray to deep } \\
\text { olive-gray (LI) }\end{array}$ & $\begin{array}{l}\text { Olivaceous black } \\
\text { (1) (XLVI) to } \\
\text { black }\end{array}$ & None \\
\hline Czapek-Dox & Moderate & $\begin{array}{l}\text { Velvety to slight } \\
\text { floccose, thin, } \\
\text { smooth }\end{array}$ & $\begin{array}{l}\text { Andover green } \\
\text { (XLVII), light } \\
\text { olive-gray to } \\
\text { olive-gray (LI) }\end{array}$ & $\begin{array}{l}\text { Olivaceous black } \\
\text { (3) (LI) to black }\end{array}$ & None \\
\hline $\begin{array}{l}\text { Potato } \\
\text { dextrose }\end{array}$ & Good & $\begin{array}{l}\text { Velvety, } \\
\text { moderately } \\
\text { raised, radiately } \\
\text { wrinkled }\end{array}$ & $\begin{array}{l}\text { Andover green } \\
\text { (XLVII), olive-gray to } \\
\text { deep olive-gray (LI) } \\
\text { with a pale olive-gray } \\
\text { (LI) edge }\end{array}$ & $\begin{array}{l}\text { Iron gray }(\mathrm{LI}) \text { to } \\
\text { black }\end{array}$ & None \\
\hline Glucose & Moderate & $\begin{array}{l}\text { Velvety to slightly } \\
\text { floccose, thin, } \\
\text { smooth }\end{array}$ & $\begin{array}{l}\text { Light olive-gray, } \\
\text { olive-gray to deep } \\
\text { olive-gray (LI) }\end{array}$ & $\begin{array}{l}\text { Iron gray (LI) to } \\
\text { black }\end{array}$ & None \\
\hline Oatmeal & $\begin{array}{l}\text { Poor to } \\
\text { moderate }\end{array}$ & $\begin{array}{l}\text { Velvety, thin, } \\
\text { smooth }\end{array}$ & $\begin{array}{l}\text { Olive-gray, deep } \\
\text { olive-gray to dark } \\
\text { olive-gray (LI) }\end{array}$ & Same as surface & None \\
\hline $\begin{array}{l}\text { Phytone } \\
\text { yeast extract }\end{array}$ & Excellent & $\begin{array}{l}\text { Velvety, highly } \\
\text { raised, radiately } \\
\text { wrinkled }\end{array}$ & $\begin{array}{l}\text { Andover green } \\
\text { (XLVII), light } \\
\text { olive-gray, olive- } \\
\text { gray to deep } \\
\text { olive-gray (LI) }\end{array}$ & $\begin{array}{l}\text { Dark mouse gray } \\
\text { (LI) to black }\end{array}$ & $\begin{array}{l}\text { Capucine } \\
\text { yellow (III) }\end{array}$ \\
\hline V-8 Juice & Good & $\begin{array}{l}\text { Velvety to } \\
\text { funiculose, thin } \\
\text { to slightly } \\
\text { raised, smooth }\end{array}$ & $\begin{array}{l}\text { Light olive-gray, } \\
\text { olive-gray to deep } \\
\text { olive-gray (LI) }\end{array}$ & $\begin{array}{l}\text { Dark olive-gray to } \\
\text { olivaceous } \\
\text { black (3) (LI) }\end{array}$ & None \\
\hline
\end{tabular}


Fig. 1. Structures of IL- $1 \beta$ and TNF- $\alpha$ production inhibitors produced by a fungus, Oidiodendron griseum CL37215.

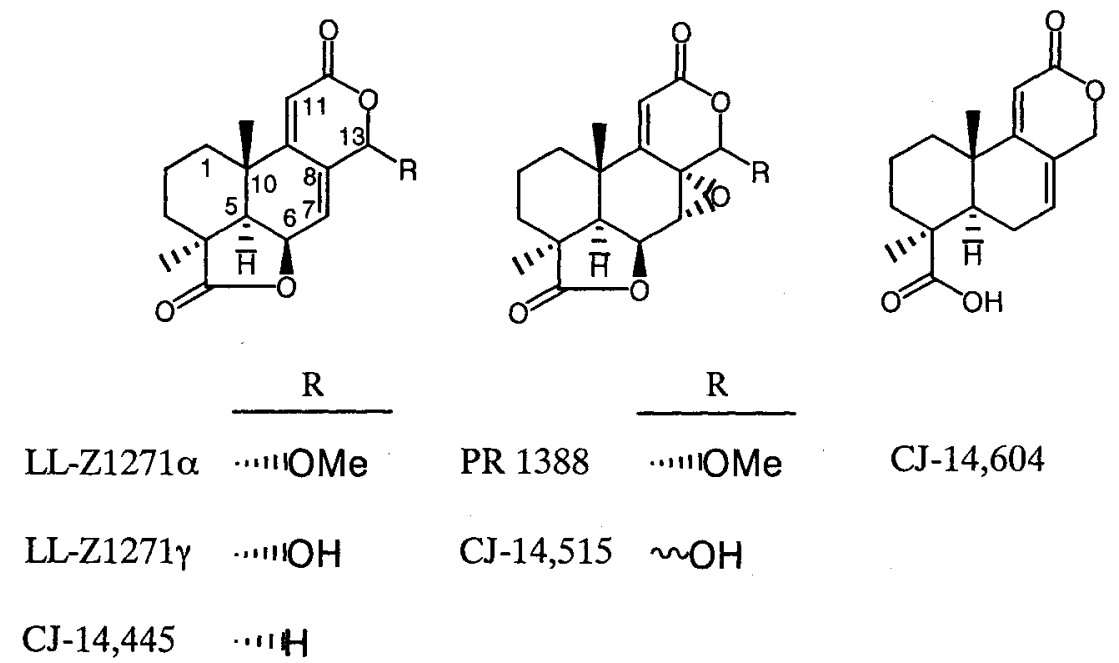

YMC Co. Ltd., Kyoto, Japan). Three diterpenes, LLZ1271 $\alpha(0.8 \mathrm{mg}), \mathrm{CJ}-14,445$ (2.4 $\mathrm{mg})$ and PR 1388 (101.8 $\mathrm{mg}$ ), were isolated from the precipitate portion by eluting with $\mathrm{MeCN}-0.1 \% \mathrm{TFA}$ in $\mathrm{H}_{2} \mathrm{O}(40: 60)$ at a flow rate of 8 $\mathrm{ml} /$ minute. Other three diterpenes, LL-Z1271 $\gamma$ (20.8 $\mathrm{mg}$ ), CJ-14,515 (17.6 mg) and CJ-14,604 (13.7 mg), were from the supernatant one with $\mathrm{MeOH}-\mathrm{H}_{2} \mathrm{O}(40: 60)$ at a flow rate of $10 \mathrm{ml} / \mathrm{minute}$.

\section{Structural Elucidation}

The structure of $\mathrm{CJ}-14,515$ was speculated by the comparison of its spectral properties with those of PR 1388. The UV spectrum showed maximum absorption at $225 \mathrm{~nm}$, suggesting the presence of $\alpha, \beta$-unsaturated lactone. The IR absorption bands at 1,770 and $1,694 \mathrm{~cm}^{-1}$ implied the presence of $\gamma$ - and $\delta$-lactone, respectively. The HRFAB-MS gave a parent ion peak at $m / z 305.104$ [(M$\mathrm{H})^{-}$; calcd. for $\left.\mathrm{C}_{16} \mathrm{H}_{17} \mathrm{O}_{6}, 305.099\right]$, indicating the loss of $\mathrm{CH}_{2}$. The ${ }^{1} \mathrm{H}$ and ${ }^{13} \mathrm{C}$ NMR spectra showed that its structure was similar to that of PR 1388 ${ }^{11}$, except for the absence of $\mathrm{CH}$ at $\mathrm{C}-13$ and $\mathrm{CH}_{3}$ at $\mathrm{C}-17$. On the hypothesis that the proton and carbon signals of hemiacetal methine were not observed in the NMR measurement, we proposed the hemiacetal structure of CJ-14,515 as shown in Fig. 1. This structure was proved by the hydrolysis of PR 1388. PR 1388 was hydrolyzed in a $3: 1: 1$ mixture of $\mathrm{AcOH}, \mathrm{H}_{2} \mathrm{O}$ and THF at $70^{\circ} \mathrm{C}$ and the isolated compound was compared with CJ-14,515. Both compounds gave identical ${ }^{1} \mathrm{H}$ NMR spectra. Thus, the structure of CJ-14,515 was determined as shown in Fig. 1, although the configuration of the hydroxyl group remains to be elucidated. The physico-chemical properties of CJ-14,515 were previously disclosed in our patent literature ${ }^{12)}$.

\section{Biological Properties}

As shown in Table 2, the diterpenes inhibited both IL- $1 \beta$ and TNF- $\alpha$ production with $\mathrm{IC}_{50}$ s of the range from 0.049 to $100 \mu \mathrm{M}$. They showed weaker inhibitory activity against leucine uptake than IL-1 $\beta$ and TNF- $\alpha$ production inhibition.

\section{Discussion}

We isolated 6 diterpenes, LL-Z1271 $\alpha$, LL-Z1271 $\gamma$, CJ14,445, PR 1388, CJ-14,604 and CJ-14,515 (a new analog) from the fermentation broth of a fungus, $O$. griseum CL37215. LL-Z1271 $\alpha$ and LL-Z1271 $\gamma$ were originally isolated from a fungus, Acrostalagmus sp. as a potent antifungal agent useful for ringworm infection in guinea pigs $^{13)}$. CJ-14,445 synthesized from LL-Z1271 $\gamma$ by sodium borohydride reduction was reported as a plant growth inhibitor $^{14)}$. PR 1388 was isolated from a strain of $O$. truncatum $^{11)}$. CJ-14,604 was reported as an intermediate 
Table 2. $\mathrm{IC}_{50}$ values of the diterpenes for IL- $1 \boldsymbol{\beta}$ production, TNF- $\alpha$ production and leucine uptake.

\begin{tabular}{lccc}
\hline Compound & \multicolumn{3}{c}{$\mathrm{IC}_{50}(\mu \mathrm{M})$} \\
\cline { 2 - 4 } & IL-1 $\beta$ production & TNF- $\alpha$ production & Leucine uptake \\
\hline LL-Z1271 $\alpha$ & 0.049 & 3.0 & 11 \\
LL-Z1271 & 69 & 11 & 120 \\
CJ-14,445 & 1.2 & 1.3 & 5.5 \\
PR 1388 & 1.5 & 4.7 & 78 \\
CJ-14,515 & 9.8 & 11 & 160 \\
CJ-14,604 & 82 & 100 & $>360$ \\
\hline
\end{tabular}

Each value is an average of triplicates.

during the total synthesis of LL-Z1271 $\alpha^{15)}$. These diterpenes inhibited IL-1 $\beta$ and TNF- $\alpha$ production and were less effective, against general protein synthesis in human whole blood. LL-Z1271 $\alpha$ showed the most potent and selective inhibition against IL- $1 \beta$ production $\left(\mathrm{IC}_{50}=0.049\right.$ $\mu \mathrm{M}, 60$-fold $v$ s. TNF- $\alpha$ production and 220 -fold $v s$. leucine uptake). Epoxidation of the double bond between $\mathrm{C}-7$ and C-8 in LL-Z1271 $\alpha$ reduced the inhibitory activity against IL-1 $\beta$ production (PR 1388). The selectivity of LL-Z1271 $\alpha$ against IL- $1 \beta$ production was changed by substitution at $\mathrm{C}$ 13 position (e.g., LL-Z1271 $\gamma$ and CJ-14,515). Cleavage of the $\gamma$-lactone ring resulted in a remarkable decrease of the activities (CJ-14,604). The preliminary structure-activity relationships (SAR) study of isolated diterpenes suggests the followings: 1) the methoxy group at $\mathrm{C}-13$ and the double bond between $\mathrm{C}-7$ and $\mathrm{C}-8$ critically participate in the potent inhibitory activity against IL-1 $\beta$ production, 2) the $\mathrm{C}-13$ position is important for the selectivity between IL- $1 \beta$ and TNF- $\alpha$ production, and 3) the $\gamma$-lactone moiety is essential for the activities. The understanding of the SAR on the diterpenes may provide useful information on designing a new type of IL- $1 \beta$ and/or TNF- $\alpha$ production inhibitors.

\section{Experimental}

\section{General}

Spectral and physico-chemical data were obtained on the following instruments: UV, JASCO Ubest-30; IR, Shimadzu IR-470; NMR, JEOL JNM-GX270 updated with an LSI-11/73 host computer, TH-5 tunable probe and version 1.6 software; FAB-MS, JEOL JMS-700; Optical rotations, JASCO DIP-370 with a $5-\mathrm{cm}$ cell.
Producing Microorganism

The producing microorganism CL37215 was isolated from a soil collected in Tsu, Mie Prefecture, Japan. The culture was single-block or smear inoculated from a block or a spore suspension of malt extract agar slant onto plates of identification media. The plates were incubated at $25^{\circ} \mathrm{C}$ for 14 days under complete darkness. Then, the observations were made for cultural characteristics and temperature studies. The colors were determined by comparisons with color chips from Color Standards and Color Nomenclature ${ }^{16)}$. For the identification of the fungus, the following media were used: cornmeal agar ${ }^{17}$, Czapeksucrose agar ${ }^{18)}$, malt extract agar ${ }^{18)}$, glucose agar (glucose $50 \mathrm{~g}$, monobasic potassium phosphate $1 \mathrm{~g}$, magnesium sulfate $0.5 \mathrm{~g}$, potassium nitrate $2 \mathrm{~g}$, agar $20 \mathrm{~g}$ and distilled water 1 liter), oatmeal agar (oatmeal $30 \mathrm{~g}$, agar $15 \mathrm{~g}$ and distilled water 1 liter), phytone yeast extract agar (BBL Microbiology Systems), potato dextrose agar (peeled potato $100 \mathrm{~g}$, dextrose $10 \mathrm{~g}$, agar $20 \mathrm{~g}$ and tap water 1 liter), and V8 juice agar (ATCC medium $343^{19)}$ ). The growth range of temperature was determined on malt extract agar.

\section{Fermentation}

The strain CL37215 was maintained on a potato dextrose agar slant (Difco Laboratories, Detroit, MI, USA). A vegetative cell suspension from the slant was used to inoculate into a $500-\mathrm{ml}$ Erlenmeyer flask containing $100 \mathrm{ml}$ of a seed medium (potato dextrose broth $2.4 \%$, yeast extract $0.5 \%$ and agar $0.1 \%$ ). The flask was shaken at $26^{\circ} \mathrm{C}$ for 4 days on a rotary shaker $(7-\mathrm{cm}$ throw at $210 \mathrm{rpm})$. Five $\mathrm{ml}$ of aliquots were inoculated into four 500-ml flasks containing $150 \mathrm{ml}$ of the seed medium, and shaken at $26^{\circ} \mathrm{C}$ for 4 days. The second seed cultures were inoculated into four 6 -liter jar fermentors containing 3 liters of a production medium (glucose $3 \%$, malt extract $1.5 \%$, yeast extract $0.5 \%$, 
$\mathrm{MgSO}_{4} \cdot 7 \mathrm{H}_{2} \mathrm{O} 0.05 \%$ and $\mathrm{KH}_{2} \mathrm{PO}_{4} 0.1 \%$, pH 6.0). The fermentation was carried out at $26^{\circ} \mathrm{C}$ for 7 days with agitation at $1,700 \mathrm{rpm}$ and aeration at a rate of 3 liters/minute.

\section{Acid Hydrolysis of PR 1388}

A mixture of PR $1388(50.0 \mathrm{mg}, 6.41 \mathrm{mmol})$ and $\mathrm{AcOH}$ $\mathrm{H}_{2} \mathrm{O}-\mathrm{THF}(3: 1: 1,10.0 \mathrm{ml})$ was stirred at $70^{\circ} \mathrm{C}$ for 75 hours. The reaction mixture was then concentrated in vacuo to give white powder: ${ }^{1} \mathrm{H}$ NMR $\left(\mathrm{CD}_{3} \mathrm{OD}\right) \delta 6.03(1 \mathrm{H}, \mathrm{s})$, $5.06(\mathrm{dd}, J=4.3,1.0 \mathrm{~Hz}), 4.02(1 \mathrm{H}, \mathrm{d}, J=1.0 \mathrm{~Hz}), 2.16(1 \mathrm{H}$, $\mathrm{m}), 1.92(1 \mathrm{H}, \mathrm{d}, J=4.3 \mathrm{~Hz}), 1.74(3 \mathrm{H}, \mathrm{m}), 1.53(2 \mathrm{H}, \mathrm{m})$, $1.27(3 \mathrm{H}, \mathrm{s}), 1.11(3 \mathrm{H}, \mathrm{m})$; LRFAB-MS $m / z 307[\mathrm{M}+\mathrm{H}]^{+}$.

\section{TNF- $\alpha$ Production Assay}

Heparinized human whole blood diluted 4-fold with RPMI 1640 medium was dispensed into $80 \mu 1$ per each well in 96-well microplates. Then, $10 \mu 1$ of each sample was added into each well. The microplates were incubated with $10 \mu \mathrm{g} / \mathrm{ml}$ of lipopolysaccharide (Sigma, St. Louis, MO, USA) for 4 hours at $37^{\circ} \mathrm{C}$ in a humidified atmosphere containing $5 \% \mathrm{CO}_{2}$. TNF- $\alpha$ content was assessed with the L929 cytotoxicity assay. L929 cells $\left(2.5 \times 10^{4}\right.$ cells $)$ in $90 \mu \mathrm{l}$ of E-MEM medium containing $1 \%$ fetal calf serum and 0.5 $\mu \mathrm{g} / \mathrm{ml}$ of actinomycin D (Sigma, St. Louis, MO, USA) were placed per each well in 96-well microplates. An aliquot (10 $\mu 1)$ of the supernatant was added to each well and incubated for 18 hours at $37^{\circ} \mathrm{C}$ in a humidified atmosphere containing $5 \% \mathrm{CO}_{2}$. After the incubation, the plates were rinsed with PBS( $(-)$ and stained for 10 minutes with $0.4 \%$ crystal violet in $\mathrm{MeOH}$. The plates were washed with distilled water and dried. Fifty $\mu$ l of methanol was added to each well to dissolve the crystal violet, and the plates were read on a microplate reader (Model 3550, BIO-RAD Laboratories, Hercules, CA, USA) at $595 \mathrm{~nm}$.

\section{IL-1 $\beta$ Production Assay}

IL- $1 \beta$ levels in the supernatants prepared by the same method as the TNF- $\alpha$ assay were analyzed by an ELISA method using an IL-1 $\beta$ assay kit (Japan Immunoresearch Laboratories Co., Ltd., Takasaki, Japan).

\section{Leucine Uptake Assay}

Ten $\mathrm{ml}$ of heparinized human whole blood was centrifuged at $1,400 \mathrm{rpm}$ for 5 minutes and then plasma was removed. After the human whole blood obtained were dispensed into a $250-\mathrm{ml}$ tube, $90 \mathrm{ml}$ of $0.83 \% \mathrm{NH}_{4} \mathrm{Cl}$ was added to the tube and then the tube was kept for 30 minutes on ice. After the tube was centrifuged at $1,400 \mathrm{rpm}$ for 5 minutes, the supernatant was decanted. The cells were suspended in $30 \mathrm{ml}$ of $0.83 \% \mathrm{NH}_{4} \mathrm{Cl}$ and kept for 10 minutes on ice. Again, the tube was centrifuged at 1,400 rpm for 5 minutes and then the supernatant was decanted. The cells were washed with PBS(-) followed by centrifugation at $1,400 \mathrm{rpm}$ for 5 minutes, and then the supernatant was decanted. To the cell pellet, the plasma and leucine-free MEM supplemented with penicillinstreptomycin and L-glutamine were added (the total volume $9 \mathrm{ml}$ ). After phytohemagglutinin (Sigma) was added to the cell suspension (the final concentration of $10 \mu \mathrm{g} / \mathrm{ml}$ ), the suspension was dispensed into $90 \mu \mathrm{l}$ per each well in 96well microplates. Then, $10 \mu \mathrm{l}$ of each sample was added into each well. The microplates were incubated overnight at $37^{\circ} \mathrm{C}$ in a humidified atmosphere containing $5 \% \mathrm{CO}_{2}$ prior to the addition of $3.7 \mathrm{kBq}$ of $\left[{ }^{3} \mathrm{H}\right]$ leucine (New England Nuclear, Boston, MA, USA) diluted with leucine-free MEM. After incubation for 4 hours at $37^{\circ} \mathrm{C}$, the cells in each well were transferred to glass filter membranes (Wallac, Turku, Finland) using a micro cell harvester (Micro96 Harvester, SKATRON Instruments AS, Lier, Norway). The radioactivity was counted in a scintillation counter (1205 Betaplate, Wallac).

\section{Acknowledgments}

The authors are grateful to their colleagues, Dr. TAISUKE INAGAKI and Dr. ATsushi NAGAHISA for their helpful advice.

\section{References}

1) DinaRello, C. A.: Inflammatory cytokines: interleukin-1 and tumor necrosis factor as effector molecules in autoimmune diseases. Curr. Opin. Immunol. 3: 941 948,1991

2) Geiger, T.; H. Towbin, A. Cosenti-Vargas, O. Zingel, J. Arnold, C. Rordorf, M. Glatt \& K. Vosveck: Neutralization of interleukin- $1 \beta$ activity in vivo with a monoclonal antibody alleviates collagen-induced arthritis in DBA/ 1 mice and prevents the associated acute-phase response. Clin. Exp. Rheumatol. 11: 515 522, 1993

3) Schorlemmer, H. U.; E. J. Kanzy, K. D. Langner \& R. KURRLE: Immunomodulatory activity of recombinant IL1 receptor (IL-1-R) on models of experimental rheumatoid arthritis. Agents Actions 39: C113 C116, 1993

4) Tracey, K. J.; Y. Fong, D. G. Hesse, K. R. Manogue, A. T. Lee, G. C. Kuo, S. F. Lowry \& A. Cerami: Anticachectin/TNF monoclonal antibodies prevent septic shock during lethal bacteraemia. Nature 330: 662 664, 1987

5) SMith, E. F. III; M. J. Slivjak, J. O. Bartus \& K. M. ESSER: SK\&F 86002 inhibits tumor necrosis factor formation and improves survival in endotoxemic rats. $\mathbf{J}$. Cardiovasc. Pharmacol. 18: 721 728, 1991

6) MuraKami, K.; F. Kobayashi, R. IKegawa, M. Koyama, 
N. Shintani, T. Yoshida, N. Nakamura \& T. Kondo: Metalloproteinase inhibitor prevents hepatic injury in endotoxemic mice. Eur. J. Pharmacol. 341: 105 110, 1998

7) Kalden, J. R. \& B. Manger: Biologic agents in the treatment of inflammatory rheumatic diseases. Curr. Opin. Rheumatol. 10: 174 178, 1998

8) ARend, W. P.; M. MalyaK, C. J. Guthridge \& C. Gabay: Interleukin-1 receptor antagonist: role in biology. Annu. Rev. Immunol. 16: 27 55, 1998

9) Moreland, L. W.: Inhibitors of tumor necrosis factor for rheumatoid arthritis. J. Rheumatol. 26 suppl. 57: 7 15, 1999

10) BARRon, G. L.: New species and new records of Oidiodendron. Can. J. Bot. 40: 589 607, 1962

11) Andersen, N. R.; P. R. Rasmusse, C. P. Falshaw \& T. J. KING: The relative and absolute configuration of clerocidin and its cometabolites. Tetrahedron Lett. 25: 469 472, 1984

12) ICHIKaWA, K.; M. IKUnaKa, N. KoJima, H. Nishida \& N. YoshiKaWA (Pfizer Inc.): Terpenoid lactone compounds and their production process. EP 933373A1, Jan. 29,
1998

13) Ellestad, G. A.; R. H. Evans, Jr. \& M. P. Kunstmann: Structure of a $\mathrm{C}_{17}$ antifungal terpenoid from an unidentified Acrostalagmus species. J. Amer. Chem. Soc. 91: 2134 2136, 1969

14) Sato, M.; T.-I. Ruo, T. Hayashi, H. Kakisawa, T. MiYaKi, H. Yamamoto \& K. FuJisaWa: Structure of $\mathrm{C}_{16}$ terpenes from Acrostalagmus NRRL-3481. Tetrahedron Lett. 25: 2183 2186, 1974

15) Barrero, A. F.; J. F. Sánchez \& J. Elmerabet: An efficient synthesis of the antifungal dilactone LL$\mathrm{Z} 1271 \alpha$ and of other biologically active compounds. Tetrahedron Lett. 36: 5251 5254, 1995

16) RoBert, R.: Color Standards and Color Nomenclature, 1912

17) Carmichael, J. W.: Geotrichum candidum. Mycologia 49: 820 830, 1957

18) Raper, K. B. \& D. I. Fennell: The Genus Aspergillus, Baltimore, The Williams \& Wilkins, pp. 36 38, 1965

19) ATCC Media Handbook, American Type Culture Collection, p. 17, 1984 